\title{
Effect of Vitamins (pyridoxine and nicotinic acid), Thiamine-Hcl and Myo-Inositol at Different Concentrations on Free Amino Acids and Indoles Content of Embryogeinic Callus of in vitro Date Oalm (Sakkoty and Bartamuda Cultivar)
}

\author{
Sherif F. El sharabasy ${ }^{1, a^{*}}$, Hussein A. Bosila ${ }^{2}$, Abdel-Aal W. B. ${ }^{1}$, \\ Bayome M. Mansour ${ }^{2}$ and Abdel-Monem A. Bana ${ }^{1}$ \\ ${ }^{1}$ The Central Lab of Date Palm Researches and Development, ARC, Giza, Egypt \\ ${ }^{2}$ Floriculture, Medicinal\&Aromatic Plants. Dept., Fac. of Agric., Al-Azhar University, Cairo Egypt \\ asharabasydates@yahoo.com
}

Keywords: vitamins, amino acid, indoles, embryogenic callus, tissue culture, date palm

\begin{abstract}
The potential of using tissue culture technique for the production of some bioactive compounds since it allows the manipulation of the biosynthetic routes to increase the production and accumulation of specific compounds. This study was conducted to investigate the effect of vitamins (pyridoxine and nicotinic acid), thiamine-Hcl at different cocentrations $(0.5,1.0$ \& 2.0 $\mathrm{mg} / \mathrm{l}$ ) and myo-inositol at different concentrations (25, 50, and 100mg/l) at different cocentrations supplemented in MS basal nutrient medium of embryogenic callus of date palm on the production of secondary metabolites of amino acids and indoles. Tow egyption cultivars (Sakkoty and Bartamuda cultivars) of date palm were used. Pyridoxine concentration at 0.5mg/l was the most effective concentration in the production of amino acids and indoles from embryonic callus of the tow studied cultivars of date palm. Nicotinic acid at $0.5 \mathrm{mg} / \mathrm{l}$ showed also the best results of production of amino acids and indoles from embryogenic callus of two cultivars. Acording to thiamine at $2 \mathrm{mg} / \mathrm{l}$ concentration was the most effective in inducing the highest significant value of amino acids and indoles from embryonic callus of two cultivars of date palm. Myo-inositol concentration at $25 \mathrm{mg} / \mathrm{l}$ produced the highest significant value of amino acids and indoles.
\end{abstract}

\section{Introduction}

Many higher plants are major sources of natural product used as pharmaceuticals, agrochemicals, flavor and fragrance ingredients, food additives, and pesticides [1]. The search for new plant derived. In the search for alternatives to production of desirable medicinal compounds from plants, biotechnological approaches, specifically, plant tissue cultures, are found to have potential as a supplement to traditional agriculture in the industrial production of bioactive plant metabolites [2]. Date palm tree Phoenix dactylifera L. is a multipurpose tree from whole tree, the cultivation of this crop was distributed in North Africa and Middle East specially in Arabian Peninsula. Date palm tree can accumulate many chemicals in their tissues, as primary metabolites containing carbohydrates and proteins, and secondary metabolites which are produced from primary ones [3,4]. The yield of secondary compounds in plants cells can be enhanced by precursor feeding in culture medium it has been a normal and a popular approach to increase this bioactive compounds [5]. secondary metabolite formation has shown that the media components have an influence on metabolism [6]. Vitamins, myoinositol and thiamine$\mathrm{HCl}$ are considered important copmonents which induce plant cell growth also thier role in stimulated the bioactve metabolites as precursors has been reported [6-9]. The aim of this work is 
to study the effect of some vitamins (Pyridoxine hydrochloride, Nicotinic acid, Thiamine hydrochloride, Myo- inositol ) on (free amino acids content, total indols content) in embryogeinic callus stage of in vitro date palm (Sakkoty and Bartamuda cultivars).

\section{Materials and Methods}

Callus explants of two cultivars Bartamuda and Sakkoty were produced from indirect protocol of date palm micropropagation discribed by $[10,11]$.

In this study received embryonic callus explants for both cultivars were cultured on basic nutrient medium for callus formation which composed of MS basal medium [12], supplemented $30 \mathrm{~g} / \mathrm{l}$ sucrose and $3.0 \mathrm{~g} / \mathrm{l}$ activated charcoal with $40 \mathrm{mg} / \mathrm{l}$ adenine - sulfate, $200 \mathrm{mg} / \mathrm{l}$ glutamine,

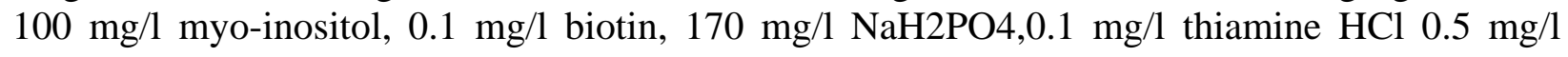
pyridoxine, $0.5 \mathrm{mg} / \mathrm{l}$ nicotinic acid, $3.0 \mathrm{mg} / \mathrm{l}$ 2- isopentenyl adenine (2iP) + $10.0 \mathrm{mg} / \mathrm{l}$ 2,4 -D dichlorophenoxy acetic acid (2,4 - D).

Callus explants of tow cultivars Bartamuda and Sakkoty were produced from indirect protocol of date palm micropropagation discribed by [10,11].

In this study recived embryonic callus explants for both cultivars were cultured on basic nutrient medium for callus formation which composed of MS basal medium [12], supplemented $30 \mathrm{~g} / \mathrm{l}$ sucrose and $3.0 \mathrm{~g} / \mathrm{l}$ activated charcoal with $40 \mathrm{mg} / \mathrm{L}$ adenine - sulfate, 200

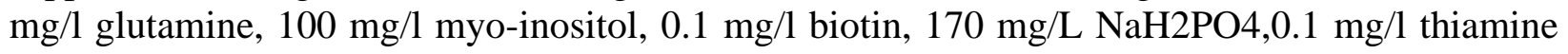
HCL $0.5 \mathrm{mg} / \mathrm{l}$ pyridoxine,0.5 mg/l nicotinic acid, $3.0 \mathrm{mg} / \mathrm{L} \quad$ 2- isopentenyl adenine (2iP) + 10.0 mg/l 2,4 -D dichlorophenoxy acetic acid $(2,4-\mathrm{D})$. The studied treatments were added as followed:-

\section{Effect of vitamins}

Effect of Pyridoxine hydrochloride concentration on secondary metabolites in embryogenic callus.

Pyridoxine hydrochloride concentration:
a) $0.5 \mathrm{mg} / \mathrm{l}$
b) $1.0 \mathrm{mg} / \mathrm{l}$
c) $2.0 \mathrm{mg} / \mathrm{l}$.

Effect of Nicotinic acid concentration on secondary metabolites in embryogenic callus.

Nicotinic acid concentration:
a) $0.5 \mathrm{mg} / \mathrm{l}$
b) $1.0 \mathrm{mg} / \mathrm{l}$
c) $2.0 \mathrm{mg} / \mathrm{l}$.

Effect of thiamine hydrochloride concentrations on secondary metabolites in embryogenic callus.

\section{Effect of Thiamine-Hcl concentrations:}
a) $0.5 \mathrm{mg} /$
b) $1.0 \mathrm{mg} / \mathrm{l}$
c) $2.0 \mathrm{mg} / \mathrm{l}$.

\section{Effect of Myo- inositol concentrations}
a) $25 \mathrm{mg} / \mathrm{l}$
b) $50 \mathrm{mg} / \mathrm{l}$
c) $100 \mathrm{mg} / \mathrm{l}$.

$6.0 \mathrm{~g} / \mathrm{l}$ agar were used to solidified culture medium which were distributed in culture jars (250 $\mathrm{ml}$ ); each jar contained $25 \mathrm{ml}$ of culture nutrient medium. Culture jars were immediately capped with polypropylene closure autoclaved at $121^{\circ} \mathrm{C}$ at $1.05 \mathrm{~kg} / \mathrm{cm}^{2}$ for $20 \mathrm{~min}$. The cultured jars were incubated under total darkness at $27 \pm 1^{\circ} \mathrm{C}$ and data were recorded every (6 weeks) for three subcultures on total steroids (mg/g dry weight).

Callus sampels were collected from all studied treatments of the micro elements compounds, manganese sulfate (), zinc sulfate $\left(\mathrm{MnSO}_{4} \cdot 4 \mathrm{H}_{2} \mathrm{O}\right)$ heptahydrate $\left(\mathrm{ZnSO}_{4} .7 \mathrm{H}_{2} \mathrm{O}\right)$ and copper sulfate $\left(\mathrm{CuSO}_{4} .5 \mathrm{H}_{2} \mathrm{O}\right)$ for both Bartamuda and Sakkoty cv. for the following assay.

\section{Determination of free amino acids}

Total amino nitrogen or free amino acids were determined according to Rosein [13]. For assay, one $\mathrm{ml}$ of sample was pipetted out into a series of test tubes, and then total volume made up to 4 $\mathrm{ml}$ with distilled water. One $\mathrm{ml}$ of ninhydrin reagent (4\%, $4 \mathrm{~g}$ ninhydrin was dissolved in $50 \mathrm{ml}$ 
acetone and $50 \mathrm{ml}$ acetate buffer) was added to each tube, mixed well, and the tubes were kept in a boiling water bath for $15 \mathrm{~min}$. Then, the tubes were cooled and the volume was made up to 10 $\mathrm{ml}$ in measuring flask with ethanol $50 \%$. The pink color developed was measured using a spectrophotometer at $570 \mathrm{~nm}$ DL-alanine. The concentration of total amino nitrogen as DLalanine were calculated from the standard curve.

\section{Extraction of Indoles and Phenols}

One gram of fresh samples in three replicates were sectioned into minute pieces and extracted with $5 \mathrm{ml}$ cold methanol $80 \%$ and stored in cold condition for $24 \mathrm{~h}$. The combined extracts were collected and filtered. Then, the volume of sample was raised up to known volume with cold methanol.

\section{A-Determination of Total Indoles}

The total indoles were determined in the methanolic extract using p-dimethyl amino benzaldehyde (PDAB) reagent, $1 \mathrm{~g}$ was dissolved in $50 \mathrm{ml} \mathrm{HCl}$ conc. and $50 \mathrm{ml}$ ethanol $95 \%$ ) test according to Larsen et al. [14]. One $\mathrm{ml}$ of aliquot methanolic extract was pipetted into a test tube, then $4 \mathrm{ml}$ of PDAB reagent was added and incubated at $30-40{ }^{\circ} \mathrm{C}$ for $1 \mathrm{~h}$. The intensity of the resultant color was spectrophotometerically measured at $530 \mathrm{~nm}$. A standard curve was established which refer to the relationship between different concentrations of IAA and their corresponding absorbance values.

\section{B-Determination of Total Phenols}

Phenols determination was carried out according to Danial and George [15]. For estimation of total phenols, $1 \mathrm{ml}$ of the methanol tissue extract was added to $0.5 \mathrm{ml}$ of Folin-Ciocalteu's Phenol Reagent and shaken $3 \mathrm{~min}$. Then, $1 \mathrm{ml}$ saturated Na2CO3 (25 \% w/v) plus $17.5 \mathrm{ml}$ distilled water added. The mixtures were left for one hour at $30-40{ }^{\circ} \mathrm{C}$. Optical density of these samples was measured by a colorimeter using wavelength $730 \mathrm{~nm}$. Concentrations of total phenols in different samples were calculated as $\mathrm{mg}$ phenol/100g FW. Amount of total phenolic compounds was calculated according to standard curve of pyrogalol (99.5\%).

\section{Statistical analysis}

The obtained data were subjected to analysis of variance. The mean values were compared using LSD test at the $5 \%$ level of probability. The data were tabulated and statistically factorial analysed according to the randomized complete block design with three replicates Snedecor \& Cochran [16].

\section{Results and Discussion}

\section{Effect of Pyridoxine- HCl on total amino acids content (mg/g fresh weight).}

Data in Table 1 clearly showed that no significant differences were found between the two cultivars under investigation (0.99, $0.94 \mathrm{mg} / \mathrm{g}$ fresh weight respectively), the pyridoxine concentration $(0.5 \mathrm{mg} / \mathrm{l})$ was the most effective as it induced the highest significant value (1.65 $\mathrm{mg} / \mathrm{g}$ fresh weight), concerning the interaction between cultivars and pyridoxine concentrations, these results illustrated that the highest significant value (1.65 $\mathrm{mg} / \mathrm{g}$ fresh weight) was for Sakkoty and Bartamuda cultivars embryogenic callus grown on medium contained( $0.5 \mathrm{mg} / \mathrm{l}$ ) pyridoxine. The lowest value $(0.47 \mathrm{mg} / \mathrm{g}$ fresh weight) was for Bartamuda cultivar embryogenic callus grown on medium contained $(1.0 \mathrm{mg} / \mathrm{l})$ pyridoxine. 
Table 1: Effect of Pyridoxine -HCl on total amino acids content ( $\mathrm{mg} / \mathrm{g}$ fresh weight).

\begin{tabular}{|l|c|c|c|c|}
\hline \multirow{2}{*}{ Cultivar (A) } & \multicolumn{5}{|l|}{ Pyridoxine- HCL mg/l (B) } \\
\cline { 2 - 5 } & $\mathbf{0 . 5}$ & $\mathbf{1 . 0}$ & $\mathbf{2 . 0}$ & Mean (A) \\
\hline Bartamuda & 1.65 & 0.47 & 0.70 & 0.99 \\
\hline Sakkoty & 1.65 & 0.54 & 0.77 & 0.94 \\
\hline Mean (B) & 1.65 & 0.51 & 0.74 & \\
\hline L.S.D 0.05: A=N.S, B $=0.19, \mathrm{AB}=0.27$ \\
\hline
\end{tabular}

2. Effect of Pyridoxine- $\mathrm{HCl}$ on total indoles content (mg/g fresh weight).

Table 2: Effect of Pyridoxine $\mathrm{HCl}$ on total indoles content ( $\mathrm{mg} / \mathrm{g}$ fresh weight).

\begin{tabular}{|c|c|c|c|c|}
\hline \multirow{2}{*}{ Cultivar (A) } & \multicolumn{4}{|c|}{ Pyridoxine HCL mg/l(B) } \\
\cline { 2 - 5 } & $\mathbf{0 . 5}$ & $\mathbf{1 . 0}$ & $\mathbf{2 . 0}$ & Mean (A) \\
\hline Bartamuda & 0.50 & 0.21 & 0.18 & 0.30 \\
\hline Sakkoty & 0.59 & 0.30 & 0.15 & 0.35 \\
\hline Mean (B) & 0.55 & 0.25 & 0.16 & \\
\hline L.S.D 0.05: A=0.03, B=0.041, AB= 0.057 \\
\hline
\end{tabular}

Data in Table 2 clearly showed that, significant differences were found between the two cultivars under investigation $(0.30,0.35 \mathrm{mg} / \mathrm{g}$ fresh weight respectively), the pyridoxine concentration $(0.5 \mathrm{mg} / \mathrm{l})$ was the most effective as it induced the highest significant value $(0.55$ $\mathrm{mg} / \mathrm{g}$ fresh weight), concerning the interaction between cultivars and pyridoxine concentrations, the highest significant value $(0.59 \mathrm{mg} / \mathrm{g}$ fresh weight) was for Sakkoty cultivar embryogenic callus grown on medium contained( $0.5 \mathrm{mg} / \mathrm{l})$ pyridoxine. The lowest value $(0.15 \mathrm{mg} / \mathrm{g}$ fresh weight) was for Sakkoty cultivar embryogenic callus grown on medium contained $2.0 \mathrm{mg} / \mathrm{l}$ Pyridoxine. 


\section{Effect of Nicotinic acid on total amino acids content ( $\mathrm{mg} / \mathrm{g}$ fresh weight).}

Table 3: Effect of Nicotinic acid on total amino acids content ( $\mathrm{mg} / \mathrm{g}$ fresh weight).

\begin{tabular}{|c|c|c|c|c|}
\hline \multirow{2}{*}{ Cultivar (A) } & \multicolumn{5}{|c|}{ Nicotinic acid mg/l (B) } \\
\cline { 2 - 5 } & $\mathbf{0 . 5}$ & $\mathbf{1 . 0}$ & $\mathbf{2 . 0}$ & Mean (A) \\
\hline Bartamuda & 0.72 & 0.49 & 0.22 & 0.48 \\
\hline Sakkoty & 0.65 & 0.45 & 0.18 & 0.42 \\
\hline Mean (B) & 0.68 & 0.47 & 0.20 & \\
\hline L.S.D 0.05: A=N.S, B= $0.081, \mathrm{AB}=0.115$ \\
\hline
\end{tabular}

Data in Table 3 clearly showed that no significant differences were found between the two cultivars under investigation $(0.48,0.42 \mathrm{mg} / \mathrm{g}$ fresh weight respectively), the nicotinic acid concentration $(0.5 \mathrm{mg} / \mathrm{l})$ was the most effective as it produced the highest significant value $(0.68$ $\mathrm{mg} / \mathrm{g}$ fresh weight), concerning the interaction between cultivars and nicotinic acid concentrations, the highest significant value $(0.72 \mathrm{mg} / \mathrm{g}$ fresh weight) was for Bartamuda cultivar embryogenic callus grown on medium contained( $0.5 \mathrm{mg} / \mathrm{l})$ nicotinic acid. The lowest value $(0.18 \mathrm{mg} / \mathrm{g}$ fresh weight) was for Sakkoty cultivar embryogenic callus grown on medium contained (2.0 mg/l) nicotinic acid.

\section{Effect of Nicotinic acid on total indoles content (mg/g fresh weight).}

Table 4: Effect of Nicotinic acid on total indoles content ( $\mathrm{mg} / \mathrm{g}$ fresh weight).

\begin{tabular}{|c|c|c|c|c|}
\hline \multirow{2}{*}{ Cultivar (A) } & \multicolumn{4}{|c|}{ Nicotinic acid mg/l (B) } \\
\cline { 2 - 5 } & $\mathbf{0 . 5}$ & $\mathbf{1 . 0}$ & $\mathbf{2 . 0}$ & Mean (A) \\
\hline Bartamuda & 0.70 & 0.46 & 0.18 & 0.45 \\
\hline Sakkoty & 0.71 & 0.42 & 0.12 & 0.42 \\
\hline Mean (B) & 0.70 & 0.44 & 0.15 & \\
\hline L.S.D 0.05: A=N.S, B=0.070, AB $=0.099$ \\
\hline
\end{tabular}

Data in Table 4 showed that no significant differences were found between the two cultivars under investigation $(0.45,0.42 \mathrm{mg} / \mathrm{g}$ fresh weight respectively), the nicotinic acid concentration $(0.5 \mathrm{mg} / \mathrm{l})$ was the most effective as it induced the highest significant value $(0.70 \mathrm{mg} / \mathrm{g}$ fresh weight) then came $(0.44$ and $0.15 \mathrm{mg} / \mathrm{g}$ fresh weight respectively), concerning the interaction between cultivars and nicotinic acid concentrations, the highest significant value $(0.71 \mathrm{mg} / \mathrm{g}$ fresh weight) was for Sakkoty cultivar embryogenic callus was grown on medium contained( $0.5 \mathrm{mg} / \mathrm{l})$ nicotinic acid. The lowest value $(0.12 \mathrm{mg} / \mathrm{g}$ fresh weight) was for Sakkoty cultivar embryogenic callus grown on medium contained (2.0 mg/l) nicotinic acid. 


\section{Effect of thiamine-Hcl on total amino acids content (mg/g fresh weight).}

Table 5: Effect of thiamine on total amino acids content ( $\mathrm{mg} / \mathrm{g}$ fresh weight).

\begin{tabular}{|l|l|l|l|c|}
\hline \multirow{2}{*}{ Cultivar (A) } & \multicolumn{4}{|l|}{ Thiamine HCl mg/l (B) } \\
\cline { 2 - 5 } & $\mathbf{0 . 5}$ & $\mathbf{1 . 0}$ & $\mathbf{2 . 0}$ & Mean (A) \\
\hline Bartamuda & 0.26 & 0.19 & 0.50 & 0.31 \\
\hline Sakkoty & 0.13 & 0.19 & 0.42 & 0.24 \\
\hline Mean (B) & 0.19 & 0.19 & 0.46 & \\
\hline L.S.D 0.05: A=0.046, B= $0.057, \mathrm{AB}=0.081$ \\
\hline
\end{tabular}

Data in Table 5 showed that there are significant differences were found between the two cultivars under investigation ( $0.31,0.24 \mathrm{mg} / \mathrm{g}$ fresh weight respectively), the thiamine concentration $(2.0 \mathrm{mg} / \mathrm{l})$ was the most effective as it induced the highest significant value $(0.46$ $\mathrm{mg} / \mathrm{g}$ fresh weight), concerning the interaction between cultivars and thiamine concentrations, the highest significant value $(0.50 \mathrm{mg} / \mathrm{g}$ fresh weight) was for Bartamuda cultivar embryogenic callus grown on medium contained( $2.0 \mathrm{mg} / \mathrm{l})$ thiamine. The lowest value $(0.13 \mathrm{mg} / \mathrm{g}$ fresh weight) was for Sakkoty cultivar embryogenic callus grown on medium contained (0.5 mg/l) thiamine.

\section{Effect of Thiamine on total indoles content (mg/g fresh weight).}

Table 6: Effect of thiamine on total indoles content $(\mathrm{mg} / \mathrm{g}$ fresh weight).

\begin{tabular}{|l|l|l|l|c|}
\hline \multirow{2}{*}{ Cultivar (A) } & \multicolumn{4}{|l|}{ Thiamine HCl mg/l(B) } \\
\cline { 2 - 5 } & $\mathbf{0 . 5}$ & $\mathbf{1 . 0}$ & $\mathbf{2 . 0}$ & Mean (A) \\
\hline Bartamuda & 0.12 & 0.26 & 0.62 & 0.33 \\
\hline Sakkoty & 0.14 & 0.34 & 0.77 & 0.42 \\
\hline Mean (B) & 0.13 & 0.30 & 0.70 & \\
\hline L.S.D 0.05: A=0.033, B=0.040, AB $=0.575$ \\
\hline
\end{tabular}

Data in Table 6 clearly showed that significant differences were found between the two cultivars under investigation $(0.33,0.42 \mathrm{mg} / \mathrm{g}$ fresh weight respectively), the thiamine concentration $(2.0 \mathrm{mg} / \mathrm{l})$ was the most effective as it resulted in the highest significant value (0.70 $\mathrm{mg} / \mathrm{g}$ fresh weight), concerning the interaction between cultivars and thiamine 
concentrations, the results illustrated that the highest significant value $(0.77 \mathrm{mg} / \mathrm{g}$ fresh weight) was for Bartamuda cultivar embryogenic callus grown on medium contained( $2.0 \mathrm{mg} / \mathrm{l})$ thiamine. The lowest value (0.12 mg/g fresh weight) was for Bartamuda cultivar embryogenic callus grown on medium contained $(0.5 \mathrm{mg} / \mathrm{l})$ thiamine.

\section{Effect of myo-inositol on total amino acids content (mg/g fresh weight).}

Table. 7: Effect of myo-inositol on total amino acids content (mg/g fresh weight).

\begin{tabular}{|l|l|l|l|c|}
\hline \multirow{2}{*}{ Cultivar (A) } & \multicolumn{4}{|l|}{ Myo-inositol mg/l (B) } \\
\cline { 2 - 5 } & $\mathbf{2 5}$ & $\mathbf{5 0}$ & $\mathbf{1 0 0}$ & Mean (A) \\
\hline Bartamuda & 1.20 & 0.60 & 0.64 & 0.81 \\
\hline Sakkoty & 1.00 & 0.61 & 0.60 & 0.73 \\
\hline Mean (B) & 1.10 & 0.60 & 0.62 & \\
\hline L.S.D 0.05: A=N.S, B=0.14, $\mathrm{AB}=0.19$ \\
\hline
\end{tabular}

Data in Table 7 showed that no significant differences were found between the two cultivars under investigation $(0.81,0.73 \mathrm{mg} / \mathrm{g}$ fresh weight respectively), the myo-inositol concentration $(25 \mathrm{mg} / \mathrm{l})$ was the most effective as it induced the highest significant value $(1.10 \mathrm{mg} / \mathrm{g}$ fresh weight), concerning the interaction between cultivars and myo-inositol concentrations, the highest significant value(1.20 mg/g fresh weight) was for Bartamuda cultivar embryogenic callus grown on medium contained ( $25 \mathrm{mg} / \mathrm{l})$ myo-inositol. The lowest value $(0.60 \mathrm{mg} / \mathrm{g}$ fresh weight) was for Sakkoty cultivar embryogenic callus grown on medium contained (100 mg/l) myo-inositol.

\section{Effect of Myo-inositol on total indoles content (mg/g fresh weight).}

Table. 8: Effect of myo-inositol on total indoles content ( $\mathrm{mg} / \mathrm{g}$ fresh weight).

\begin{tabular}{|l|l|l|l|c|}
\hline Cultivar (A) & \multicolumn{4}{|c|}{ Myo-inositol mg/l (B) } \\
\hline & $\mathbf{2 5}$ & $\mathbf{5 0}$ & $\mathbf{1 0 0}$ & Mean (A) \\
\hline Bartamuda & 0.61 & 0.23 & 0.27 & 0.37 \\
\hline Sakkoty & 0.67 & 0.23 & 0.26 & 0.39 \\
\hline Mean (B) & 0.64 & 0.23 & 0.26 & \\
\hline L.S.D 0.05: A=N.S, B=0.040, AB $=0.057$ \\
\hline
\end{tabular}

Data in Table 8 clearly showed that no significant differences were found between the two cultivars under investigation $(0.37,0.39 \mathrm{mg} / \mathrm{g}$ fresh weight respectively), the myo-inositol concentration $(25 \mathrm{mg} / \mathrm{l})$ was the most effective as it produced the highest significant value $(0.64$ $\mathrm{mg} / \mathrm{g}$ fresh weight), concerning the interaction between cultivars and myo-inositol 
concentrations, the highest significant value $(0.67 \mathrm{mg} / \mathrm{g}$ fresh weight) was for Bartamuda cultivar embryogenic callus grown on medium contained( $25 \mathrm{mg} / \mathrm{l})$ myo-inositol. The lowest value $(0.23$ $\mathrm{mg} / \mathrm{g}$ fresh weight) was for Bartamuda and Sakkoty cultivars the embryogenic callus grown on medium contained (50 mg/l) myo-inositol.

Secondary metabolite production can be induced by medium optimizations $[17,18]$.Obviously, in many cases, rigorously controlled plant in vitro cultures can generate the same valuable natural products [5]. Vitamins are nitrogenous substances required in trace amounts to serve catalytic functions in enzyme systems. Plant cell grown in vitro are capable of synthesizing essential vitamins in suboptimal quantities; thus,culture media are often supplemented with vitamins to enhance growth. Various standard media formulations and modifications there of show wide differences in vitamin composition $[5,19]$. Thiamine is essential for many plant cells, it is also involved in cell biosynthesis and metabolism. Myoinositol has been described as a natural constituent of plant which involved in cell membrane permeability. It stimulated the cell division when added at low concentrations to the culture medium [20-22]. On the light of our results these compounds additives have induced the content of free amino acids content and indole content in date palm callus dependent on the concentration.

\section{Summary}

Studies in this area could lead to the successful manipulation of secondary metabolism and could significantly increase the amounts of the compounds. It should be possible to achieve the synthesis of a wide range of compounds in date palm callus cultures.

\section{References}

[1] R. Muhaidat, M.A. Al-Qudah, O. Samir, J.H. Jacob,E. Hussein, I.N. Al-Tarawneh, E. Bsoul, S.T.Orabi, Phytochemical investigation and in vitro antibacterial activity of essential oils from Cleome droserifolia (Forssk.) Delile and C. trinervia Fresen.(Cleomaceae), South African J. Bot. 99 (2015) 21-8. https://doi.org/10.1016/j.sajb.2015.03.184

[2] M. Asif, Chemistry and antioxidant activity of plants containing some phenolic compounds, Chem. Int. 1 (2015), pp. 35-52.

[3] S. Gantait, M.M. El-Dawayati, J. Panigrahi, C. Labrooy, S.K. Verma, The retrospect and prospect of the applications of biotechnology in (Phoenix dactylifera L.), App. Microbial, Biotech. 102 (2018) 8229-8259. https://doi.org/10.1007/s00253-018-9232-x

[4] R. Al-Alawi, J. Al-Mashiqri, J. Al-Nadabi, B. Al-Shihi, Y. Baq, Date palm tree (Phoenix dactylifera L.) natural products and therapeutic options, Front Plant Sci 8 (2017) 1-12. https://doi.org/10.3389/fpls.2017.00845

[5] N.A Fadzliana, S. Rogayah, N.A. Shaharuddin, O.A. Janna, Addition of L-Tyrosine to Improve Betalain Production in Red Pitaya Callus, Pertanika J. Tropical Agr. Sci. 40-4 (2017) 521-532.

[6] A.P. Ling, S.L. Ong, H. Sobri, Strategies in enhancing secondary metabolites production in plant cell cultures, Med Aromat Plant Sci Biotechnol. 5 (2011) 94-101.

[7] A. Pérez, L. Nápoles, C. Carvajal, M. Hernandez, JC. Lorenzo, Effect of sucrose, inorganic salts, inositol, and thiamine on protease excretion during pineapple culture in temporary immersion bioreactors, In Vitro Cellular \& Developmental Biology-Plant, 40-3 (2004) 311-316. https://doi.org/10.1079/ivp2004529 
[8] A. Jacob, N. Malpathak, Manipulation of MS and B5 components for enhancement of growth and solasodine production in hairy root cultures of Solanum khasianum Clarke, Plant cell, tiss org cult. 80-3 (2005) 247-57. https://doi.org/10.1007/s11240-004-0740-2

[9] E.F. George, M.A. Hall, GJ De Klerk, The component of plant tissue culture media II. Organic additives, osmotic and $\mathrm{pH}$ effects and support system, In: Plant propagation by tissue culture the background (3rd Edn), Springer The Netherland 1 (2010) 115-174.

https://doi.org/10.1007/978-1-4020-5005-3_4

[10] Z. E. Zayed, Enhanced Indirect Somatic Embryogenesis from Shoot-Tip Explants of Date Palm by Gradual Reductions of 2, 4-D Concentration, In Date Palm Biotechnology Protocols, Humana Press, New York 1 (2017) 77-88. https://doi.org/10.1007/978-1-4939-7156-5_7

[11] M.M. El-Dawayati, H.S. Ghazzawy, M. Munir, Somatic embryogenesis enhancement of date palm cultivar Sewi using different types of polyamines and glutamine amino acid concentration under in-vitro solid and liquid media conditions, Int J Biosci 12 (2018) 149-159. https://doi.org/10.12692/ijb/12.1.149-159

[12] T. Murashige, F. Skoog, A revised medium for rapid growth and bioassays with tobacco tissue cultures, Physiol. Plant 15 (1962) 473-497. https://doi.org/10.1111/j.1399-

3054.1962.tb08052.x

[13] H. Rosein, A modified ninhydrin coloremetric analysis for amino acids. Archives of Biochemistry and Biophysics 67 (1957) 10-15. https://doi.org/10.1016/0003-9861(57)90241-2

[14] P. Larsen, A. Harbo, S. Klungsour, T. Asheim, On the biogenesis of some indol compounds in Acetobacter xylinum, Physiologia Plantarum, 15 (1962) 552 - 655.

https://doi.org/10.1111/j.1399-3054.1962.tb08058.x

[15] H.D. Danial, C.M. George, Peach seed dormancy in relation to endogenous inhibitors and applied growth substances, Journal of the American Society for Horticultural Science, 17 (1972) 651- 654 .

[16] G.W. Snedecor, W.G. Cochran, Statisical Methods, Oxford and J.B.H. Publishing Co., 6th edition, 1980, pp. 507.

[17] M.I. Dias, M.J. Sousa, R.C. Alves, Ferreira IC. Exploring plant tissue culture to improve the production of phenolic compounds: A review, Industrial Crops and Products, 82 (2016) 9-22. https://doi.org/10.1016/j.indcrop.2015.12.016

[18] I. Smetanska, Production of secondary metabolites using plant cell cultures, In Food biotech Springer, Berlin, Heidelberg (2008)187-228.

[19] C.L. Marbun, N. Toruan-Mathius, C. Utomo, T. Liwang, Micropropagation of embryogenic callus of oil palm (Elaeis guineensis Jacq.) using temporary immersion system, Procedia Chemistry, 2015. https://doi.org/10.1016/j.proche.2015.03.018

[20] Bettendorff L. Thiamine, Handbook of Vitamins, 5th Edition. 2014, pp. 267-323.

[21] T. Thorpe, S.E.A Yeung, GJ. de Klerek, A. Robert, E.F. George, The component of plant tissue culture media II. Organic additives, osmotic and $\mathrm{pH}$ effects and support system, In: Plant propagation by tissue culture the background (3red Edn), Springer The Netherland 1 (2010) 115174. https://doi.org/10.1007/978-1-4020-5005-3_4

[22] A.P. Ling, S.L. Ong, H. Sobri, Strategies in enhancing secondary metabolites production in plant cell cultures, Med Aromat Plant Sci Biotechnol. 5 (2011) 94-101. 